\title{
Synthesis and Structure of Fused $\alpha$-Oligothiophenes with Up to Seven Rings
}

\author{
Xinnan Zhang, Adrien P. Côté, and Adam J. Matzger*
}

Department of Chemistry and the Macromolecular Science and Engineering Program, University of Michigan, 930 N. University, Ann Arbor, MI 48109-1055

\section{Supporting Information}

Table of contents

1. Experimental section.

2. Crystal data and structure refinement of $\mathbf{1 , 7}$ and $\mathbf{1 2}$ (including packing motif of $\mathbf{7}$ and 12).

3. Powder X-ray diffraction of $\mathbf{1}$ and $\mathbf{2}$.

4. Normalized UV-vis and fluorescence spectra comparison of $\mathbf{7}, \mathbf{1 2}, \mathbf{1}, \mathbf{2}, \alpha-$ terthiophene and $\alpha$-quaterthiophene.

5. Cyclic voltammetry of $\mathbf{1}$.

\section{Experimental section.}

General. 2,5-Dibromo-thieno[3,2- $b$ ]thiophene and 2,6-dibromo-dithieno[3,2- $b ; 2^{\prime}, 3^{\prime}$ d] thiophene were prepared according to the literature procedure. ${ }^{1,2} \mathrm{THF}$, toluene and $\mathrm{CH}_{2} \mathrm{Cl}_{2}$ were dried by passage through a column packed with activated alumina. UV-vis absorption spectra of $\mathbf{1}, \mathbf{7}$ and $\mathbf{1 2}$ were taken on a CARY 300 Bio UV-visible spectrophotometer in $\mathrm{CH}_{2} \mathrm{Cl}_{2}$ solution $\left(<10^{-6} \mathrm{M}\right)$ at room temperature. Because compound 2 is not soluble enough in $\mathrm{CH}_{2} \mathrm{Cl}_{2}$ to measure the UV-vis absorption spectrum, these data were recorded in $\mathrm{THF}$ solution. Emission spectra were collected on a FluoroMax-2 spectrometer in $\mathrm{CH}_{2} \mathrm{Cl}_{2}$ solution $\left(<10^{-8} \mathrm{M}\right)$. The fluorescence spectra are independent of the excitation wavelength in the region between 330-370 nm for compound 1 and 350-390 $\mathrm{nm}$ for $\mathbf{2}$. The emission spectrum of $\mathbf{2}$ was collected in THF solution and no significant shift was observed when compared to the spectrum taken in $\mathrm{CH}_{2} \mathrm{Cl}_{2}$. Crystals of 1 suitable for single crystal X-ray diffraction were obtained from a $\mathrm{CHCl}_{3}$ solution upon cooling. The crystals of $\mathbf{7}$ and $\mathbf{1 2}$ were obtained by slow evaporation from hexanes.
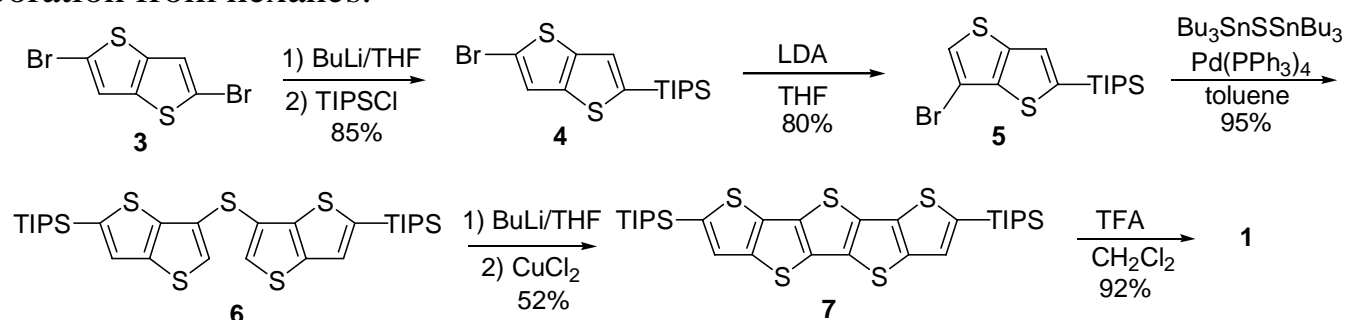

(5-Bromo-thieno[3,2-b]thiophen-2-yl)-triisopropyl-silane (4) 
Butyllithium (1.6 $\mathrm{M}$ in hexanes, $28.1 \mathrm{~mL}, 44.9 \mathrm{mmol}$ ) was added dropwise to a solution of 2,5-dibromothieno[3,2- $b$ ] thiophene $(13.37 \mathrm{~g}, 44.9 \mathrm{mmol})$ in THF $(500 \mathrm{~mL})$ at $-78{ }^{\circ} \mathrm{C}$ under a $\mathrm{N}_{2}$ atmosphere. After stirring for $15 \mathrm{~min}$ at this temperature, triisopropylchlorosilane $(9.58 \mathrm{~mL}, 44.9 \mathrm{mmol})$ was added dropwise. The solution was stirred for another $3 \mathrm{~h}$ and allowed to warm to $0{ }^{\circ} \mathrm{C}$, followed by dilution with hexanes $(400 \mathrm{~mL})$ and quenching with brine $(300 \mathrm{~mL})$. The organic layer was collected and dried over anhydrous $\mathrm{Na}_{2} \mathrm{SO}_{4}$. After removing the solvent in vacuo, the residue was purified by column chromatography on silica gel (hexanes) to yield $4(14.3 \mathrm{~g}, 85 \%)$ as a white solid; mp 73.5-74.1 ${ }^{\circ} \mathrm{C} .{ }^{1} \mathrm{H} \mathrm{NMR}\left(400 \mathrm{MHz}, \mathrm{CDCl}_{3}, \delta\right): 1.12$ (d, $\left.J=7.3 \mathrm{~Hz}, 18 \mathrm{H}\right), 1.36$ (sep, $J$ $=7.4 \mathrm{~Hz}, 3 \mathrm{H}), 7.26(\mathrm{~s}, 1 \mathrm{H}), 7.27(\mathrm{~s}, 1 \mathrm{H}) .{ }^{13} \mathrm{C} \mathrm{NMR}\left(125 \mathrm{MHz}, \mathrm{CDCl}_{3}, \delta\right): 11.78,18.53$, 114.3, 121.9, 126.3, 136.8, 140.8, 142.9. Anal. Calcd for $\mathrm{C}_{15} \mathrm{H}_{23} \mathrm{BrSiS}_{2}$ : C, 47.98; H, 6.17. Found: C, 47.70; H, 6.08. IR (KBr): 3093 (w), 2964 (m), 2940 (s), 2885 (m), 2862 (s), 1485 (m), 1456 (m) 1294 (m), 1172 (m), 1148 (m), 1074 (m), 1016 (m), 1006 (s), 991 (m), 952 (s), 883 (s), $827(\mathrm{~m}), 801$ (s), 686 (s), 654 (s), $627(\mathrm{~m}), 562$ (m), 532 (s), 507 $\mathrm{cm}^{-1}(\mathrm{~s})$. MS (EI, 70eV) $\mathrm{m} / \mathrm{z}$ (relative intensity): 376.9 (22.5), 375.9 (100.0), 374.9 (14.4), 373.9 (75.6, $\mathrm{M}^{+}$), 333.9 (13.7), 332.9 (87.3), 332.0 (14.6), 330.9 (69.9), 309.0 (27.7), 307.0 (26.0), 305.0 (11.2), 303.0 (9.8), 293.0 (16.5), 292.0 (15.0), 291.0 (91.8), 290.0 (12.6), 289.0 (90.5), 263.0 (16.8), 261.0 (17.6), 249.0 (11.9), 247.0 (9.8), 196.1 (16.3), 186.1 (11.7), 167.0 (15.2), 162.0 (17.0), 153.1 (10.0), 131.1 (66.3), 109.0 (10.1), 106.0 (13.4), 89.0 (28.5), 75.0 (11.6).

(6-Bromo-thieno[3,2-b]thiophen-2-yl)-triisopropyl-silane (5)

To a solution of diisopropylamine $(2.80 \mathrm{~mL}, 20.0 \mathrm{mmol})$ in THF $(250 \mathrm{~mL})$ at $0{ }^{\circ} \mathrm{C}$ was added butyllithium (1.6 $\mathrm{M}$ in hexanes, $11.1 \mathrm{~mL}, 17.8 \mathrm{mmol}$ ) under a $\mathrm{N}_{2}$ atmosphere. After stirring for $30 \mathrm{~min}$ at $0{ }^{\circ} \mathrm{C}$, the flask was placed in a $-78{ }^{\circ} \mathrm{C}$ bath. Compound 4 $(5.54 \mathrm{~g}, 14.8 \mathrm{mmol}$, dissolved in $30 \mathrm{~mL}$ THF) was then added into the reaction mixture. The solution was allowed to slowly warm up to room temperature. After stirring for $17 \mathrm{~h}$, the flask was placed in a $0{ }^{\circ} \mathrm{C}$ bath, diluted with hexanes $(200 \mathrm{~mL})$, and quenched with brine $(200 \mathrm{~mL})$. The organic layer was collected and dried over anhydrous $\mathrm{Na}_{2} \mathrm{SO}_{4}$. After removing the solvent in vacuo, the product was purified by column chromatography on silica gel (hexanes) to yield $5(4.43 \mathrm{~g}, 80 \%)$ as a white solid; mp 73.6-74.2 ${ }^{\circ} \mathrm{C} .{ }^{1} \mathrm{H}$ NMR (400 MHz, $\left.\mathrm{CDCl}_{3}, \delta\right): 1.14(\mathrm{~d}, J=7.4 \mathrm{~Hz}, 18 \mathrm{H}), 1.38$ (sep, $\left.J=7.5 \mathrm{~Hz}, 3 \mathrm{H}\right), 7.27(\mathrm{~s}, 1 \mathrm{H})$, 7.39 (s, 1H). ${ }^{13} \mathrm{C} \mathrm{NMR}\left(125 \mathrm{MHz}, \mathrm{CDCl}_{3}, \delta\right): 11.76,18.52,102.3,124.6,127.7,139.5$, 140.2, 145.3. Anal. Calcd for $\mathrm{C}_{15} \mathrm{H}_{23} \mathrm{BrSiS}_{2}$ : C, 47.98; H, 6.17. Found: C, 48.23; H, 6.33. IR (KBr): 3107 (m), 2956 (s), $2941(\mathrm{~s}), 2885(\mathrm{~m}), 2862(\mathrm{~s}), 2830(\mathrm{~m}), 1474(\mathrm{~m}), 1466(\mathrm{~m})$ 1459 (s), 1379 (m), 1365 (m), 1339 (s), 1291 (m), 1167 (m), 1072 (m), 1014 (s), 998 (s), $980(\mathrm{~s}), 926(\mathrm{~m}), 919(\mathrm{~m}), 881(\mathrm{~s}), 852(\mathrm{~m}), 828(\mathrm{~s}), 815(\mathrm{~m}), 725(\mathrm{~s}), 685(\mathrm{~s}), 652(\mathrm{~s})$, $644(\mathrm{~s}), 602(\mathrm{~m}), 557(\mathrm{~m}), 536(\mathrm{~m}), 505(\mathrm{~s}), 483 \mathrm{~cm}^{-1}(\mathrm{~m})$. MS (EI, 70eV) $\mathrm{m} / \mathrm{z}$ (relative intensity): 376.9 (12.6), 375.9 (63.7), 374.9 (9.1), $373.9\left(60.6, \mathrm{M}^{+}\right), 333.0$ (23.3), 331.0 (24.7), 309.0 (33.9), 307.0 (31.4), 291.0 (38.5), 289.0 (40.1), 281.1 (12.1), 196.1 (13.7), 186.1 (11.7), 149.1 (23.3), 131.2 (100.0), 89.1 (41.1), 75.2 (17.6).

Bis(2-triisopropylsilyl-thieno[3,2-b]thiophenyl)sulfide (6)

$\mathrm{Pd}\left(\mathrm{PPh}_{3}\right)_{4}(462 \mathrm{mg}, 0.400 \mathrm{mmol})$ was added to a mixture of compound 5 (3.85 g, 10.3 $\mathrm{mmol})$ and bis(tri-n-butyltin)sulfide $(3.15 \mathrm{~g}, 5.14 \mathrm{mmol})$ in toluene $(25 \mathrm{~mL})$ under a $\mathrm{N}_{2}$ atmosphere. The solution was stirred for $24 \mathrm{~h}$ at $130{ }^{\circ} \mathrm{C}$ in a $75 \mathrm{~mL}$ pressure vessel. After 
addition of hexanes $(50 \mathrm{~mL})$, the solution was filtered and the organic layer was washed with water $(2 \times 40 \mathrm{~mL})$ and brine $(50 \mathrm{~mL})$. The organic layer was dried over anhydrous $\mathrm{Na}_{2} \mathrm{SO}_{4}$. After removing the solvent in vacuo, the residue was purified by column chromatography on silica gel (hexanes) to give $6(3.04 \mathrm{~g}, 95 \%)$ as a white solid; mp 88.0$89.5{ }^{\circ} \mathrm{C} .{ }^{1} \mathrm{H}$ NMR $\left(400 \mathrm{MHz}, \mathrm{CDCl}_{3}, \delta\right): 1.08(\mathrm{~d}, J=7.4 \mathrm{~Hz}, 36 \mathrm{H}), 1.31$ (sep, $J=7.3 \mathrm{~Hz}$, $6 \mathrm{H}), 7.30(\mathrm{~s}, 2 \mathrm{H}), 7.45$ (s, 2H). ${ }^{13} \mathrm{C} \mathrm{NMR}\left(125 \mathrm{MHz}, \mathrm{CDCl}_{3}, \delta\right): 11.70,18.50,121.2$, 127.1, 129.2, 139.0, 140.6, 146.1. Anal. Calcd for $\mathrm{C}_{30} \mathrm{H}_{46} \mathrm{Si}_{2} \mathrm{~S}_{5}: \mathrm{C}, 57.82 ; \mathrm{H}, 7.44$. Found: C, 57.61; H, 7.49. IR (KBr): 3090 (w), 2941 (s), 2917 (s), 2863 (s), 2848 (s), 1461 (s), $1291(\mathrm{~m}), 1016$ (s), 1000 (s), $985(\mathrm{~s}), 883$ (s), $823(\mathrm{~m}), 684(\mathrm{~m}), 650 \mathrm{~cm}^{-1}$ (m). MS (EI, $70 \mathrm{eV}) \mathrm{m} / \mathrm{z}$ (relative intensity): 625.1 (15.6), 624.1 (38.5), $623.1(45.0), 622.1\left(89.7, \mathrm{M}^{+}\right)$, 579.1 (14.3), 540.0 (15.2), 539.0 (40.5), 538.0 (44.2), 537.0 (100.0), 497.0 (13.9), 496.0 (15.1), 495.0 (36.6), 453.0 (14.0), 404.1 (11.2), 361.0 (16.6), 319.0 (10.0), 83.9 (16.1), 73.0 (17.2), $59.0(50.3)$.

2,6-Bis-triisopropylsilanyl-pentathienoacene (7)

Butyllithium (1.6 M in hexanes, $7.50 \mathrm{~mL}, 12.0 \mathrm{mmol}$ ) was added into a stirring solution of $6(3.11 \mathrm{~g}, 5.0 \mathrm{mmol})$ in $\mathrm{THF}(250 \mathrm{~mL})$ at $0{ }^{\circ} \mathrm{C}$ under a $\mathrm{N}_{2}$ atmosphere. After stirring for $30 \mathrm{~min}$ at this temperature, the solution was allowed to warm to room temperature and stirred for additional $2 \mathrm{~h}$. The flask was placed in a $0{ }^{\circ} \mathrm{C}$ bath, followed by addition of $\mathrm{CuCl}_{2}(1.62 \mathrm{~g}, 12.0 \mathrm{mmol})$. After stirring for $16 \mathrm{~h}$ at room temperature, the mixture was diluted with ether $(500 \mathrm{~mL})$ and filtered. The filtrate was washed with water $(250 \mathrm{~mL})$ and brine $(250 \mathrm{~mL})$ and dried over anhydrous $\mathrm{Na}_{2} \mathrm{SO}_{4}$. After removing the solvent in vacuo, the residue was purified by column chromatography on silica gel (hexanes) to yield $7(1.61 \mathrm{~g}, 52 \%)$ as a white solid; mp 222-223 ${ }^{\circ} \mathrm{C}$. UV-vis $\left(\mathrm{CH}_{2} \mathrm{Cl}_{2}\right): \lambda_{\max }(\log \varepsilon)=$ 375 (4.70), 357 (4.72), 340 (4.50), 425 (4.44), 312 (4.21) nm. ${ }^{1} \mathrm{H} \mathrm{NMR} \mathrm{(400} \mathrm{MHz,} \mathrm{CDCl}_{3}$, $\delta): 1.16(\mathrm{~d}, J=7.4 \mathrm{~Hz}, 36 \mathrm{H}), 1.40(\mathrm{sep}, J=7.5 \mathrm{~Hz}, 6 \mathrm{H}), 7.41(\mathrm{~s}, 2 \mathrm{H}) .{ }^{13} \mathrm{C} \mathrm{NMR}(125$ $\mathrm{MHz}_{\mathrm{CDCl}}$, $\delta$ ): 11.82, 18.59, 128.2, 131.0, 134.2, 136.8, 136.9, 142.1. Anal. Calcd for $\mathrm{C}_{30} \mathrm{H}_{44} \mathrm{Si}_{2} \mathrm{~S}_{5}$ : C, 58.01; H, 7.14. Found: C, 57.95; H, 7.20. IR (KBr): $3071(\mathrm{w}), 2938$ (s), 2935 (s), 2863 (s), 1462 (s), 1377 (m), 1015 (s), 996 (s), 975 (s), 883 (s), 828 (m), 685 (m), 655 (s), 650 (s), 564 (s), 517 (s), $504 \mathrm{~cm}^{-1}$ (m). MS (EI, 70eV) $\mathrm{m} / z$ (relative intensity): 623.0 (16.9), 622.0 (45.4), 621.0 (52.7), 620.0 (100.0, M+), 579.9 (10.1), 578.9 (30.0), 577.9 (34.1), 576.9 (71.6), 536.9 (14.7), 535.9 (14.9), 534.9 (36.5), 203.9 (11.6), 85.9 (10.4), 83.9 (17.0), 59.0 (20.7).

Pentathienoacene (1)

Trifluoroacetic acid $(6.0 \mathrm{~mL})$ was added to a solution of 7 (792 $\mathrm{mg}, 1.28 \mathrm{mmol})$ in $\mathrm{CH}_{2} \mathrm{Cl}_{2}(150 \mathrm{~mL})$ under a $\mathrm{N}_{2}$ atmosphere. The solution was stirred for $16 \mathrm{~h}$ in the absence of light. After addition of ethanol $(200 \mathrm{~mL})$, the precipitate was collected on a fritted funnel. The white solid was washed with ethanol and hexanes to give $\mathbf{1}(363 \mathrm{mg}, 92 \%)$ as a white solid. Compound 1 could be further purified by sublimation $\left(7.0-8.0 \times 10^{-5}\right.$ Torr, $\left.150-160{ }^{\circ} \mathrm{C}\right) ; \operatorname{mp} 308{ }^{\circ} \mathrm{C}$ dec. UV-vis $\left(\mathrm{CH}_{2} \mathrm{Cl}_{2}\right): \lambda_{\max }(\log \varepsilon)=357$ (4.52), 342 (4.56), 326 (4.37), 317 (4.44), 305 (4.32), 296 (sh, 3.56) nm. ${ }^{1} \mathrm{H}$ NMR (400 MHz, $\mathrm{CDCl}_{3}, \delta$ ): 7.32 (d, $J=5.1 \mathrm{~Hz}, 2 \mathrm{H}), 7.39(\mathrm{~d}, J=5.3 \mathrm{~Hz}, 2 \mathrm{H})$. Anal. Calcd for $\mathrm{C}_{12} \mathrm{H}_{4} \mathrm{~S}_{5}$ : C, 46.72; H, 1.31 . Found: C, 46.52; H, 1.25. IR (KBr): 3095 (w), $3081(\mathrm{w}), 1467(\mathrm{w}), 1392(\mathrm{~m}), 1375(\mathrm{~s})$, $1185(\mathrm{~m}), 1077(\mathrm{~m}), 897(\mathrm{~m}), 786(\mathrm{w}), 691(\mathrm{~s}), 625(\mathrm{~s}), 542(\mathrm{~m}), 461 \mathrm{~cm}^{-1}(\mathrm{~m})$. MS (EI, 
70eV) $\mathrm{m} / z$ (relative intensity): 310.1 (22.4), 309.1 (17.6), $308.1\left(100.0, \mathrm{M}^{+}\right), 299.0$ (7.27), 264.1 (13.0), 225 (6.21), 209.1 (5.69).
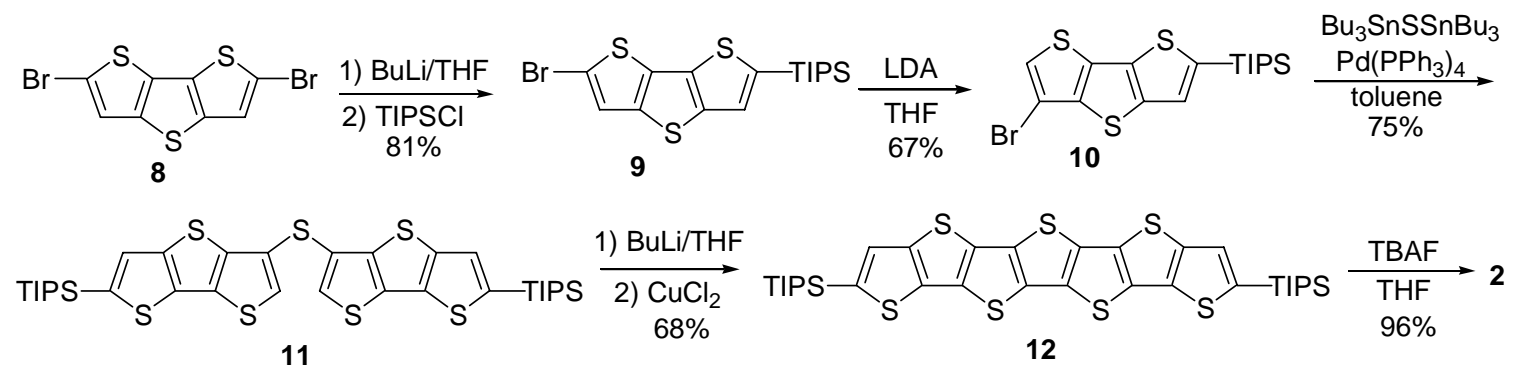

(6-Bromo-dithieno[3,2- $\left.b ; 2^{\prime}, 3^{\prime}-d\right]$ thiophen-2-yl)-triisopropyl-silane (9)

Butyllithium (1.6 M in hexanes, $3.04 \mathrm{~mL}, 4.86 \mathrm{mmol}$ ) was added dropwise to a solution of 2,6-dibromo-dithieno[3,2- $\left.b ; 2^{\prime}, 3^{\prime}-d\right]$ thiophene $(8)(1.72 \mathrm{~g}, 4.86 \mathrm{mmol})$ in THF (100 mL) at $-78{ }^{\circ} \mathrm{C}$ under a $\mathrm{N}_{2}$ atmosphere. After stirring for $15 \mathrm{~min}$ at this temperature, triisopropylchlorosilane $(1.04 \mathrm{~mL}, 4.86 \mathrm{mmol})$ was added dropwise. The solution was stirred for $3 \mathrm{~h}$ and allowed to warm up to $0{ }^{\circ} \mathrm{C}$, followed by dilution with hexanes (150 $\mathrm{mL})$ and quenching with brine $(150 \mathrm{~mL})$. The organic layer was collected and dried over anhydrous $\mathrm{Na}_{2} \mathrm{SO}_{4}$. After removing the solvent in vacuo, the residue was purified by column chromatography on silica gel (hexanes) to yield $9(1.69 \mathrm{~g}, 81 \%)$ as a white solid; mp 79.0-80.5 ${ }^{\circ} \mathrm{C} .{ }^{1} \mathrm{H} \mathrm{NMR}\left(400 \mathrm{MHz}, \mathrm{CDCl}_{3}, \delta\right): 1.14$ (d, $\left.J=7.3 \mathrm{~Hz}, 18 \mathrm{H}\right), 1.38$ (sep, $J$ $=7.3 \mathrm{~Hz}, 3 \mathrm{H}), 7.28(\mathrm{~s}, 1 \mathrm{H}), 7.37(\mathrm{~s}, 1 \mathrm{H}) .{ }^{13} \mathrm{C} \mathrm{NMR}\left(125 \mathrm{MHz}, \mathrm{CDCl}_{3}, \delta\right): 11.86,18.59$, 111.9, 123.5, 128.0, 131.1, 135.7, 137.3, 140.4, 142.5. Anal. Calcd for $\mathrm{C}_{17} \mathrm{H}_{23} \mathrm{BrSiS}_{3}$ : C, 47.31; H, 5.37. Found: C, 47.69; H, 5.50. IR (KBr): 3090 (w), 2943 (s), 2862 (s), 1458 (s), $1348(\mathrm{~m}), 1014(\mathrm{~s}), 997(\mathrm{~s}), 978(\mathrm{~s}), 881(\mathrm{~m}), 829(\mathrm{~s}), 805(\mathrm{~m}), 686(\mathrm{~s}), 651(\mathrm{~s}), 600(\mathrm{~m})$, $574(\mathrm{~s}), 521(\mathrm{~m}), 496(\mathrm{~m}), 467 \mathrm{~cm}^{-1}(\mathrm{~m})$. MS (EI, 70eV) $\mathrm{m} / \mathrm{z}$ (relative intensity): 433.9 (15.8), 433.0 (30.9), 432.0 (100.0), 431.0 (29.5), 430.0 (94.2, $\mathrm{M}^{+}$), 390.0 (10.9), 389.0 (63.4), 387.9 (15.4), 387.0 (51.2), 366.0 (10.8), 365.0 (56.8), 364.0 (12.8), 363.0 (60.0), 349.0 (13.2), 348.0 (21.7), 347.0 (73.1), 346.0 (12.5), 345.0 (65.2), 329.1 (17.6), 313.0 (11.8), 311 (10.6), 305.0 (10.4), 303.0 (10.2), 284.0 (11.1), 256.1 (11.3), 242.1 (21.7), $218.1(14.9)$.

(5-Bromo-dithieno[3,2- $b ; 2^{\prime}, 3$ '- $d$ ] thiophen-2-yl)-triisopropyl-silane (10)

To a solution of diisopropylamine $(0.700 \mathrm{~mL}, 5.00 \mathrm{mmol})$ in THF $(100 \mathrm{~mL})$ at $0{ }^{\circ} \mathrm{C}$ was added butyllithium (1.6 $\mathrm{M}$ in hexanes, $2.94 \mathrm{~mL}, 4.70 \mathrm{mmol}$ ) under a $\mathrm{N}_{2}$ atmosphere. After stirring for $30 \mathrm{~min}$ at $0{ }^{\circ} \mathrm{C}$, the flask was placed in a $-78{ }^{\circ} \mathrm{C}$ bath. Compound 9 (1.69 g, $3.93 \mathrm{mmol}$, dissolved in $10 \mathrm{~mL}$ THF) was added into the reaction mixture over $15 \mathrm{~min}$. The solution was allowed to slowly warm up to room temperature. After stirring for $17 \mathrm{~h}$, the flask was placed in a $-78{ }^{\circ} \mathrm{C}$ bath, diluted with hexanes $(100 \mathrm{~mL})$, and quenched with brine $(100 \mathrm{~mL})$. The organic layer was collected and dried over anhydrous $\mathrm{Na}_{2} \mathrm{SO}_{4}$. After removing the solvent in vacuo, the product was purified by column chromatography on silica gel (hexanes) to yield 10 (1.13 g, 67\%). ${ }^{1} \mathrm{H}$ NMR (400 MHz, $\left.\mathrm{CDCl}_{3}, \delta\right): 1.16(\mathrm{~d}, J=7.5 \mathrm{~Hz}, 18 \mathrm{H}), 1.40(\mathrm{sep}, J=7.4 \mathrm{~Hz}, 3 \mathrm{H}), 7.23(\mathrm{~s}, 1 \mathrm{H}), 7.43$ (s, $1 \mathrm{H}) .{ }^{13} \mathrm{C} \mathrm{NMR}\left(125 \mathrm{MHz}, \mathrm{CDCl}_{3}, \delta\right): 12.03,18.79,103.8,122.5,128.5,130.5,136.5$, 137.8, 143.1, 143.6. GC-MS (EI, 70eV) $\mathrm{m} / z$ (relative intensity): 432.9 (31.2), 431.9 (90.4), 430.9 (33.3), $430.0\left(100.0, \mathrm{M}^{+}\right), 390.9$ (10.1), 389.0 (50.0), 387.8 (10.9), 387.0 
(37.2), 366.9 (17.0), 365.8 (10.3), 364.9 (74.9), 362.9 (47.3), 348.0 (14.0), 347.0 (55.3), 345.0 (50.1), 336.9 (14.3), 311.1 (11.6), 283.1 (11.4), 281.2 (10.4), 275.0 (11.8), 257.0 (14.0), 256.1 (18.2), 255.0 (14.7), 242.1 (27.6), 222.1 (12.7), 218.1 (13.1), 211.1 (20.9), 131.1 (86.8), 75.1 (15.1).

Bis(2-triisopropylsilyl-dithieno[3,2- $\left.b ; 2^{\prime}, 3^{\prime}-d\right]$ thiophenyl)sulfide (11)

$\mathrm{Pd}\left(\mathrm{PPh}_{3}\right)_{4}(68.2 \mathrm{mg}, 0.0590 \mathrm{mmol})$ was added to a mixture of compound 10 (508 g, 1.18 mmol) and bis(tri-n-butyltin)sulfide $(361 \mathrm{mg}, 0.590 \mathrm{mmol})$ in toluene $(5.0 \mathrm{ml})$ under a $\mathrm{N}_{2}$ atmosphere. The solution was stirred for $24 \mathrm{~h}$ at $130{ }^{\circ} \mathrm{C}$ in a $15 \mathrm{~mL}$ pressure vessel. After addition of hexanes $(20 \mathrm{~mL})$, the solution was filtered and the organic layer was washed with water $(2 \times 20 \mathrm{~mL})$ and brine $(20 \mathrm{~mL})$. The organic layer was dried over anhydrous $\mathrm{Na}_{2} \mathrm{SO}_{4}$. After removing the solvent in vacuo, the residue was purified by column chromatography on silica gel (hexanes) to give $\mathbf{1 1}(325 \mathrm{mg}, 75 \%)$ as a yellow solid; $\mathrm{mp}$ 96.0-97.0 ${ }^{\circ} \mathrm{C}$. ${ }^{1} \mathrm{H}$ NMR (400 MHz, $\left.\mathrm{CDCl}_{3}, \delta\right): 1.11(\mathrm{~d}, J=7.5 \mathrm{~Hz}, 36 \mathrm{H}), 1.35$ (sep, $J=$ $7.4 \mathrm{~Hz}, 6 \mathrm{H}), 7.30$ (s, 2H), 7.50 (s, 2H). ${ }^{13} \mathrm{C} \mathrm{NMR}\left(125 \mathrm{MHz}, \mathrm{CDCl}_{3}, \delta\right): 11.76,18.53$, 122.2, 127.3, 128.3, 130.4, 135.8, 137.2, 143.8, 143.9. Anal. Calcd for $\mathrm{C}_{34} \mathrm{H}_{46} \mathrm{Si}_{2} \mathrm{~S}_{7}: \mathrm{C}$, 55.53; H, 6.31. Found: C, 55.92; H, 6.42. IR (KBr): 3095 (w), 2940 (s), 2862 (s), 2460 (s), $1382(\mathrm{~m}), 1345(\mathrm{~m}), 1277(\mathrm{~m}), 1015(\mathrm{~s}), 1001(\mathrm{~s}), 969(\mathrm{~s}), 882(\mathrm{~s}), 825(\mathrm{~m}), 684(\mathrm{~m}), 654$ (s), $570(\mathrm{~m}), 525(\mathrm{~m}), 500(\mathrm{~m})$. MS (EI, 70eV) $\mathrm{m} / \mathrm{z}$ (relative intensity): 737.3 (13.5), 736.4 (29.9), 735.4 (30.1), 734.4 (51.0, $\left.\mathrm{M}^{+}\right), 694.3$ (10.0), 693.3 (22.8), 692.3 (23.2), 691.3 (40.4), 651.2 (20.7), 650.2 (20.4), 649.2 (38.9), 609.2 (12.6), 608.2 (10.9), 607.2 (24.3), 204.1 (17.9), 203.1 (100.0), 135.1 (40.7), 91.1 (13.2), 87.1 (22.6), 84.0 (34.9), 77.1 (17.8), 59.0 (21.9).

2,6-Bis-triisopropylsilanyl-heptathienoacene (12)

Butyllithium (1.6 M in hexanes, $0.519 \mathrm{~mL}, 0.830 \mathrm{mmol})$ was added into a stirring solution of 11 (253 mg, $0.345 \mathrm{mmol})$ in THF $(10 \mathrm{~mL})$ at $0{ }^{\circ} \mathrm{C}$ under a $\mathrm{N}_{2}$ atmosphere. After stirring for $30 \mathrm{~min}$ at this temperature, the solution was allowed to warm up to room temperature and stirred for additional $2 \mathrm{~h}$. It was then placed in a $0{ }^{\circ} \mathrm{C}$ bath, followed by addition of $\mathrm{CuCl}_{2}(112 \mathrm{mg}, 0.830 \mathrm{mmol})$. After stirring for $16 \mathrm{~h}$ at room temperature, the mixture was diluted with ether $(50 \mathrm{~mL})$ and filtered. The filtrate was washed with water $(25 \mathrm{~mL})$ and brine $(25 \mathrm{~mL})$ and dried over anhydrous $\mathrm{Na}_{2} \mathrm{SO}_{4}$. After removing the solvent in vacuo, the residue was purified by column chromatography on silica gel (hexanes) to yield $12(172 \mathrm{mg}, 68 \%)$ as a yellow solid; mp $340{ }^{\circ} \mathrm{C} \mathrm{dec}$. UV-vis $\left(\mathrm{CH}_{2} \mathrm{Cl}_{2}\right): \lambda_{\max }(\log \varepsilon)=412$ (4.86), 389 (4.86), 370 (4.58), 334 (4.33), 319 (4.14) nm. ${ }^{1} \mathrm{H}$ NMR (400 MHz, $\mathrm{CDCl}_{3}, \delta$ ): $1.16(\mathrm{~d}, J=7.3 \mathrm{~Hz}, 36 \mathrm{H}), 1.41$ (sep, $J=7.4 \mathrm{~Hz}, 6 \mathrm{H}$ ), 7.42 (s, $1 \mathrm{H}) .{ }^{13} \mathrm{C} \mathrm{NMR}\left(125 \mathrm{MHz}, \mathrm{CDCl}_{3}, \delta\right): 11.90,18.50,128.2,131.1,132.2,132.3,134.1$, 136.8, 137.4, 142.3. Anal. Calcd for $\mathrm{C}_{34} \mathrm{H}_{44} \mathrm{Si}_{2} \mathrm{~S}_{7}$ : C, 55.68; H, 6.05. Found: C, 54.98; H, 6.02. IR (KBr): 3070 (w), 2940 (s), 2886 (m), 2862 (s), 1460 (s), 1393 (m), 1379 (s), 1366 (m), $1164(\mathrm{~m}), 1071(\mathrm{~m}), 1016$ (s), 998 (s), 963 (s), 923 (s), 881 (s), 843 (m), 824 (m), $686(\mathrm{~m}), 655(\mathrm{~s}), 584(\mathrm{~m}), 562(\mathrm{~m}), 530(\mathrm{~m}), 517(\mathrm{~s}) \mathrm{cm}^{-1}$. MS (EI, 70eV) $\mathrm{m} / \mathrm{z}$ (relative intensity): 736.1 (15.2), 735.1 (26.3), 734.1 (55.0), 733.1 (56.8), $732.1\left(\mathrm{M}^{+}\right.$, 100.0), 691.1 (19.3), 690.1 (19.4), 689.1 (35.1), 649.0 (15.0), 648.0 (15.2), 647.0 (24.4), 167.1 (15.5), 83.9 (18.0).

Heptathienoacene (2) 
Tetrabutylammonium fluoride trihydrate $(287 \mathrm{mg}, 0.913 \mathrm{mmol})$ was added to a solution of $12(66.8 \mathrm{mg}, 0.0913 \mathrm{mmol})$ in THF $(20 \mathrm{~mL})$. The solution was stirred for $14 \mathrm{~h}$ in the absence of light. The yellow precipitate was collected on a fritted funnel and washed with THF and $\mathrm{CH}_{2} \mathrm{Cl}_{2}$ to give $2(36.8 \mathrm{mg}, 96 \%)$; $\mathrm{mp}>360{ }^{\circ} \mathrm{C}$. Compound 2 could be further purified by sublimation $\left(4.0-5.0 \times 10^{-5}\right.$ Torr, $\left.230-245^{\circ} \mathrm{C}\right)$. UV-vis (THF): $\lambda_{\max }=396,378$, 359, 329, $316 \mathrm{~nm}$. Anal. Calcd for $\mathrm{C}_{16} \mathrm{H}_{4} \mathrm{~S}_{7}$ : C, 45.68; H, 0.96. Found: C, 45.77; H, 0.97. IR (KBr): 3097 (w), 3082 (w), 1394 (s), 1382 (s), 1185 (m), 1087 (m), 893 (m), 787 (m), $689(\mathrm{~m}), 642(\mathrm{~m}), 603(\mathrm{~m}) \mathrm{cm}^{-1}$. MS (EI, 70eV) $\mathrm{m} / z$ (relative intensity): 421.9 (35.1), 420.1 (25.1), $419.9\left(100.0, \mathrm{M}^{+}\right), 210.0$ (19.7).

\section{Crystal data and structure refinement of 1,7 and 12}

Single Crystal X-ray Diffraction Studies of 1: A colorless plate crystal $(0.24 \times 0.13 \times$ $0.05 \mathrm{~mm}^{3}$ ) of 1 was coated in Paratone oil and mounted on a Bruker SMART APEX CCD diffractometer while being flash frozen to $153(2) \mathrm{K}$ in a liquid $\mathrm{N}_{2}$ cooled stream of nitrogen gas. The diffractometer was equipped with a fine focus Mo-target X-ray tube ( $\lambda$ $=0.71073 \AA$, graphite monochromated) operated at $2000 \mathrm{~W}$ power $(50 \mathrm{kV}, 40 \mathrm{~mA})$; distance between the detector and crystal was $5.051 \mathrm{~cm}$. Initial scans indicated that the crystal contained a high degree of moasicity (large rocking curves of $>1.0^{\circ}$ ) and was weakly diffracting, therefore a $1.0^{\circ}$ frame width for full data collection was used to obtain usable peak profiles. The frames were collected at 153(2) K with varying $\omega$ and $\phi$ and an exposure time of $60 \mathrm{~s} /$ frame to cover one hemisphere. Unit cell parameters were determined using CELLNOW and were based on the $x y z$ centroids of 556 reflections sampled from different regions of the Ewald sphere. Frames were integrated using the SAINT (v6.02A) software package using a narrow frame algorithm. A multi-scan absorption correction was applied using SHELXTL. The structures were solved by direct methods and the subsequent difference Fourier syntheses and refined with the SHELXTL (v6.12) software package. Integration of the data in the orthorhombic cell yielded a total of 9472 reflections of which 1228 were unique and 870 were greater than $2 \sigma(I)$. The range of $\theta$ was from 1.62 to $27.25^{\circ}$. Analysis of the data showed negligible decay during collection. The structure was solved in the Pnma space group with $Z=2$ using direct methods. All non-hydrogen atoms were refined anisotropically, using six restraints, with hydrogen atoms generated as spheres riding the coordinates of their parent atoms. Final full matrix least-squares refinement on $F^{2}$ converged to $\left.R 1=0.1033(F>4 \sigma F)\right)$ and $w \mathrm{R} 2$ $=0.2358$ (all data) with $\mathrm{GOF}=1.166$. All residual electron density in the final F-map was closely associated with the lone electron pairs of the S-atoms in the model. The larger residuals reported here ultimately result from the poor moasicity of the single crystal. Nonetheless, the assignment of atom positions and scattering factors was unambiguous and the final model is an accurate representation of the material.

Sheldrick, G. M. SHELXTL, v.6.12; Bruker Analytical X-ray, Madison, WI, 2000.

SAINTPLUS, v.6.02A, Bruker Analytical X-ray, Madison, WI, 2003.

Blessing, Acta Cryst. (1995) A51 33-58. 
Table 1. Crystal data and structure refinement for $\mathbf{1 .}$

Identification code

H-T5-H

Empirical formula

C12 H4 S5

Formula weight

308.45

Temperature

153(2) K

Wavelength

$0.71073 \AA$

Crystal system

Orthorhombic

Space group

Unit cell dimensions

Pnma

\begin{tabular}{|c|c|c|}
\hline \multirow[t]{3}{*}{ Unit cell dimensions } & $a=11.171(4) \AA$ & \\
\hline & $b=25.098(9) \AA$ & $\beta=90^{\circ}$. \\
\hline & $c=3.8852(13) \AA$ & $\gamma=90^{\circ}$ \\
\hline Volume & $1089.3(6) \AA^{3}$ & \\
\hline $\mathrm{Z}$ & 2 & \\
\hline Density (calculated) & $1.881 \mathrm{Mg} / \mathrm{m}^{3}$ & \\
\hline Absorption coefficient & $1.028 \mathrm{~mm}^{-1}$ & \\
\hline $\mathrm{F}(000)$ & 624 & \\
\hline Crystal size & $0.24 \times 0.13 \times 0.05$ & \\
\hline Theta range for data collection & 1.62 to $27.25^{\circ}$. & \\
\hline Index ranges & $-14<=\mathrm{h}<=14,-32<$ & $2,-5<=1<=5$ \\
\hline Reflections collected & 9472 & \\
\hline Independent reflections & $1228[\mathrm{R}($ int $)=0.1$ & \\
\hline Completeness to theta $=27.25^{\circ}$ & $99.0 \%$ & \\
\hline Max. and min. transmission & 0.9504 and 0.7904 & \\
\hline Refinement method & Full-matrix least-s & on $\mathrm{F}^{2}$ \\
\hline Data / restraints / parameters & $1228 / 6 / 79$ & \\
\hline Goodness-of-fit on $\mathrm{F}^{2}$ & 1.142 & \\
\hline Final $R$ indices $[\mathrm{I}>2 \operatorname{sigma}(\mathrm{I})]$ & $\mathrm{R} 1=0.1033, \mathrm{wR} 2$ & \\
\hline $\mathrm{R}$ indices (all data) & $\mathrm{R} 1=0.1344, \mathrm{wR} 2$ & \\
\hline Largest diff. peak and hole & 1.166 and $-1.598 \mathrm{e}$ & \\
\hline
\end{tabular}

Single Crystal X-ray Diffraction Studies of 7: A colorless block-like crystal $(0.3 \times 0.20$ $\times 0.20 \mathrm{~mm}^{3}$ ) of 7 was coated in Paratone oil and mounted on a Bruker SMART APEX CCD diffractometer while being flash frozen to $153(2) \mathrm{K}$ in a liquid $\mathrm{N}_{2}$ cooled stream of nitrogen gas. The diffractometer was equipped with a fine focus Mo-target X-ray tube ( $\lambda$ $=0.71073 \AA$, graphite monochromated) operated at $2000 \mathrm{~W}$ power $(50 \mathrm{kV}, 40 \mathrm{~mA})$; distance between the detector and crystal was $5.051 \mathrm{~cm}$. The frames were collected at $153(2) \mathrm{K}$ with varying $\varphi$ and $\phi$ (frame width $=0.3^{\circ}$ ) with an exposure time of $30 \mathrm{~s} /$ frame 
to cover one hemisphere. Unit cell parameters was determined using CELLNOW and was based on the $x y z$ centroids of 999 reflections sampled from different regions of the Ewald sphere. Frames were integrated using the SAINT (v6.02A) software package using a narrow frame algorithm. A multi-scan absorption correction was applied using SHELXTL. The structures were solved by direct methods and the subsequent difference Fourier syntheses and refined with the SHELXTL (v6.12) software package. Integration of the data in the tetragonal cell yielded a total of 38409 reflections of which 4814 were unique and 4241 were greater than $2 \sigma(I)$. The range of $\theta$ was from 1.77 to $29.60^{\circ}$. Analysis of the data showed negligible decay during collection. The structure was solved in the $P-42{ }_{1}$ c space group with $Z=4$ using direct methods. All non-hydrogen atoms were refined anisotropically with hydrogen atoms generated as spheres riding the coordinates of their parent atoms. Final full matrix least-squares refinement on $F^{2}$ converged to $R 1=$ $0.0483(\Phi>4 \sigma F))$ and $w \mathrm{R} 2=0.1190$ (all data) with $\mathrm{GOF}=1.037$.

Sheldrick, G. M. SHELXTL, v.6.12; Bruker Analytical X-ray, Madison, WI, 2000.

SAINTPLUS, v.6.02A, Bruker Analytical X-ray, Madison, WI, 2003.

Blessing, Acta Cryst. (1995) A51 33-58.

Table 2. Crystal data and structure refinement for 7.

Identification code

Empirical formula

Formula weight

Temperature

Wavelength

Crystal system

Space group

Unit cell dimensions

Volume

Z

Density (calculated)

Absorption coefficient
TIPS-T5-TIPS

C30 H44 S5 Si2

621.13

153(2) K

$0.71073 \AA$

Tetragonal

$P-42{ }_{1} \mathrm{c}$

$$
\begin{array}{ll}
a=16.2367(15) \AA & \alpha=90^{\circ} . \\
b=16.2367(15) \AA & \beta=90^{\circ} . \\
c=13.0410(17) \AA & \gamma=90^{\circ} .
\end{array}
$$

3438.0(6) $\AA^{3}$

4

$1.200 \mathrm{Mg} / \mathrm{m}^{3}$

$0.425 \mathrm{~mm}^{-1}$ 
$\mathrm{F}(000)$

1328

Crystal size

$0.3 \times 0.2 \times 0.2 \mathrm{~mm}^{3}$

Theta range for data collection

1.77 to $29.60^{\circ}$.

Index ranges

$-22<=\mathrm{h}<=22,-22<=\mathrm{k}<=22,-18<=1<=18$

Reflections collected

38409

Independent reflections

$4814[\mathrm{R}(\mathrm{int})=0.0767]$

Completeness to theta $=29.60^{\circ}$

$99.6 \%$

Refinement method

Full-matrix least-squares on $\mathrm{F}^{2}$

Data / restraints / parameters

4814 / 0 / 168

Goodness-of-fit on $\mathrm{F}_{2}$

1.037

Final $\mathrm{R}$ indices [I>2sigma(I)]

$\mathrm{R} 1=0.0483, \mathrm{wR} 2=0.1092$

$\mathrm{R}$ indices (all data)

$\mathrm{R} 1=0.0589, \mathrm{wR} 2=0.1190$

Largest diff. peak and hole

0.701 and -0.547 e. $\AA^{-3}$

Figure 1. Packing motif of 7.

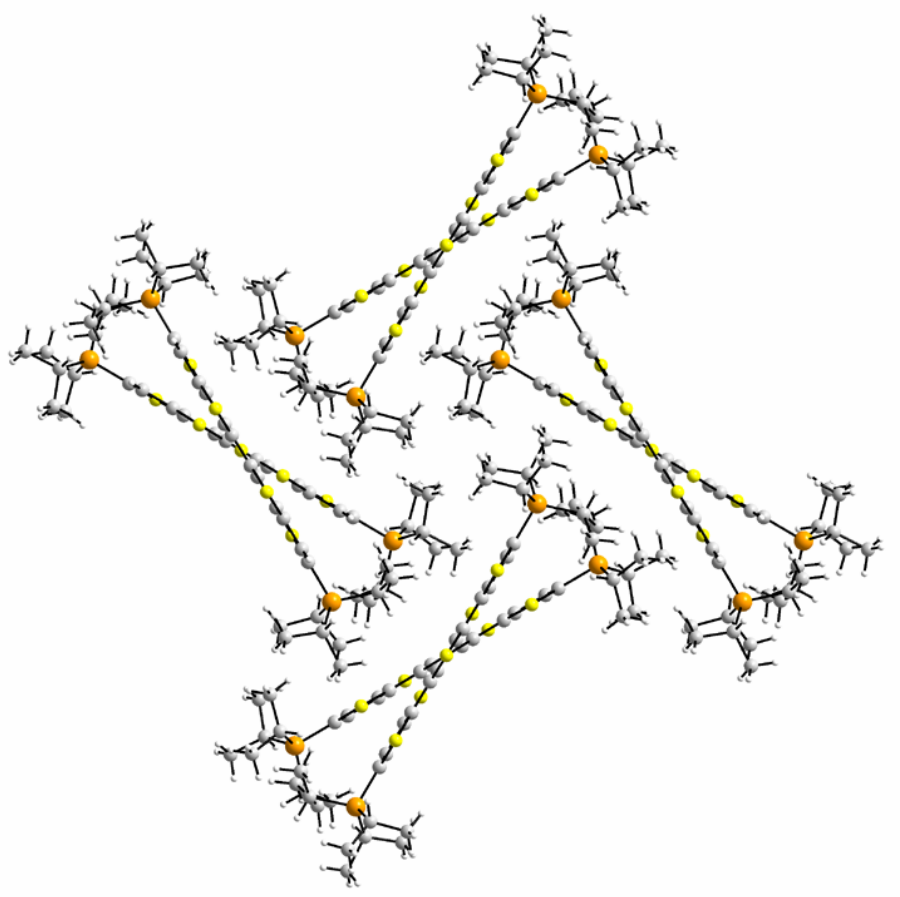

Single Crystal X-ray Diffraction Studies of 12: A yellow needle crystal $(0.40 \times 0.10 \times$ $0.10 \mathrm{~mm}^{3}$ ) of $\mathbf{1 2}$ was coated in Paratone oil and mounted on a Bruker SMART APEX CCD diffractometer while being flash frozen to $153(2) \mathrm{K}$ in a liquid $\mathrm{N}_{2}$ cooled stream of 
nitrogen gas. The diffractometer was equipped with a fine focus Mo-target X-ray tube ( $\lambda$ $=0.71073 \AA$, graphite monochromated) operated at $1800 \mathrm{~W}$ power $(45 \mathrm{kV}, 40 \mathrm{~mA})$; distance between the detector and crystal was $5.051 \mathrm{~cm}$. The frames were collected at $153(2) \mathrm{K}$ with varying $\omega$ and $\phi$ (frame width $=0.3^{\circ}$ ) with an exposure time of $30 \mathrm{~s} /$ frame to cover one hemisphere. Unit cell parameters was determined using CELLNOW and was based on the $x y z$ centroids of 999 reflections sampled from different regions of the Ewald sphere. Frames were integrated using the SAINT (v6.02A) software package using a narrow frame algorithm. A multi-scan absorption correction was applied using SHELXTL. The structures were solved by direct methods and the subsequent difference Fourier syntheses and refined with the SHELXTL (v6.12) software package. Integration of the data in the orthorhombic cell yielded a total of 68999 reflections of which 8281 were unique and 6504 were greater than $2 \sigma(I)$. The range of $\theta$ was from 1.32 to $27.56^{\circ}$. Analysis of the data showed negligible decay during collection. The structure was solved in the $P$ ccn space group with $Z=8$ using direct methods. All non-hydrogen atoms were refined anisotropically with hydrogen atoms generated as spheres riding the coordinates of their parent atoms. Final full matrix least-squares refinement on $F^{2}$ converged to $R 1=$ $0.0366(\Phi>4 \sigma F))$ and $w \mathrm{R} 2=0.0953$ (all data) with $\mathrm{GOF}=1.010$.

Sheldrick, G. M. SHELXTL, v.6.12; Bruker Analytical X-ray, Madison, WI, 2000.

SAINTPLUS, v.6.02A, Bruker Analytical X-ray, Madison, WI, 2003.

Blessing, Acta Cryst. (1995) A51 33-58.

Table 3. Crystal data and structure refinement for 12.

Identification code

Empirical formula

Formula weight

Temperature

Wavelength

Crystal system

Space group

Y $\nu \imath \tau \chi \varepsilon \lambda \lambda \delta \mu \varepsilon v \sigma \iota v \sigma$

Volume

$\mathrm{Z}$

Density (calculated)

Absorption coefficient
TIPS-T7-TIPS

C34 H44 S7 Si2

733.29

153(2) K

$0.71073 \AA$

Orthorhombic

Pccn

$$
\begin{array}{ll}
\alpha=17.9934(16) \AA & \alpha=90^{\circ} . \\
b=29.790(3) \AA & \beta=90^{\circ} . \\
c=13.4276(12) \AA & \gamma=90^{\circ} .
\end{array}
$$

7197.6(11) $\AA^{3}$

8

$1.353 \mathrm{Mg} / \mathrm{m}^{3}$

$0.529 \mathrm{~mm}^{-1}$ 
$\mathrm{F}(000)$

Crystal size

Theta range for data collection

Index ranges

Reflections collected

Independent reflections

Completeness to theta $=27.56^{\circ}$

Max. and min. transmission

Refinement method

Data / restraints / parameters

Goodness-of-fit on $\mathrm{F}_{2}$

Final $\mathrm{R}$ indices [I $>2 \operatorname{sigma}(\mathrm{I})]$

$\mathrm{R}$ indices (all data)

Largest diff. peak and hole
3104

$0.40 \times 0.10 \times 0.10 \mathrm{~mm}^{3}$

1.32 to $27.56^{\circ}$.

$-23<=\mathrm{h}<=23,-38<=\mathrm{k}<=38,-17<=\mathrm{l}<=17$

68999

$8281[\mathrm{R}(\mathrm{int})=0.0747]$

$99.4 \%$

0.9490 and 0.8150

Full-matrix least-squares on $\mathrm{F}^{2}$

$8281 / 0 / 400$

1.010

$\mathrm{R} 1=0.0366, \mathrm{wR} 2=0.0823$

$\mathrm{R} 1=0.0529, \mathrm{wR} 2=0.0953$

0.447 and -0.365 e. $\AA^{-3}$ 
Figure 2. Packing motif of 12.

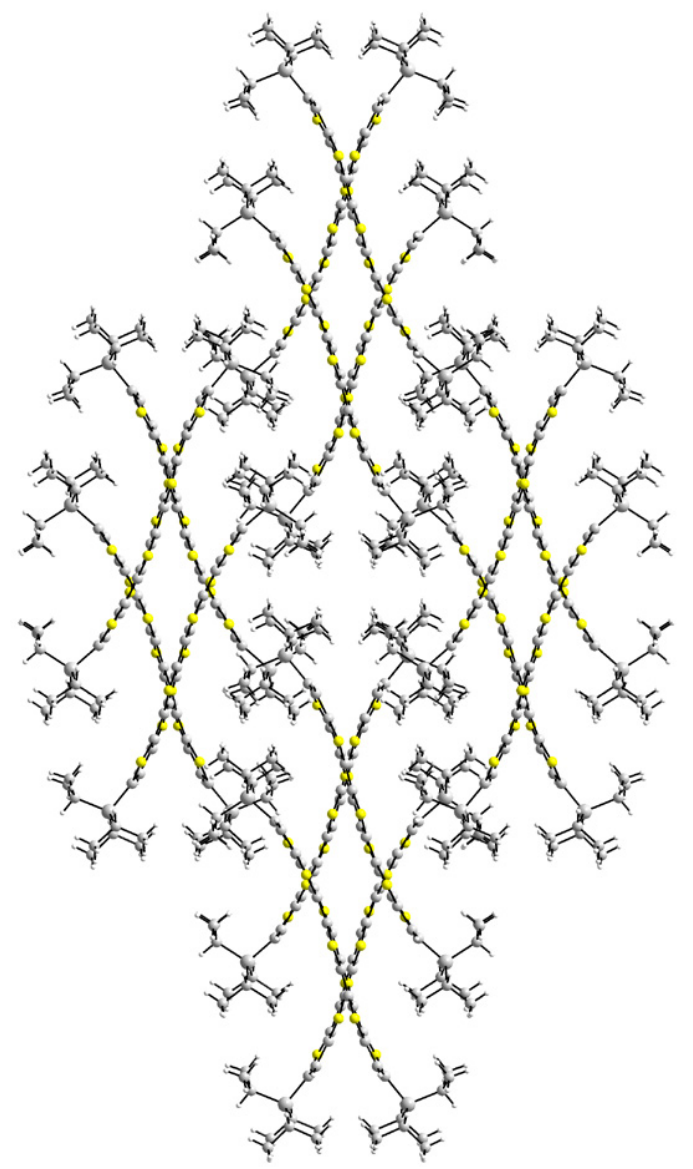

\section{Powder X-ray diffraction data of 1 and 2.}

Powder X-ray Diffraction Methods. Data for full patterns was collected on a Bruker D8-Advance diffractometer equipped with a $\mathrm{Cu}$ X-ray tube operated at $40 \mathrm{kV} 40 \mathrm{~mA}$ $(1600 \mathrm{~W}$, Ni filtered) in the Bragg-Brentano geometry. High angle data was obtained using a Bruker D8-Discover diffractometer, with incident $\mathrm{Cu}$ radiation $(40 \mathrm{kV} 40 \mathrm{~mA}$ $(1600 \mathrm{~W})$ ) collimated to a $0.5 \mathrm{~mm}^{2}$ region of the sample and scattered radiation collected using a GADDS area detection system. This latter technique was used to augment the quality of the data at high angle as a highly focused radiation flux is used in combination with a sensitive detection system. The unit cell for Compound $\mathbf{2}$ was indexed manually using the programs ChekCell ${ }^{1}$ and Crystal Cracker $^{2}$ to aid with calculations. Using the lattice parameters obtained for $\mathbf{1}$ as a starting point, zones corresponding to the $a$ and $c$ axes were readily identified and matched the experimental pattern for $\mathbf{2}$ in an orthorhombic crystal system using the Pnma space group. The value the $b$-axis was adjusted until higher [ $\left[\begin{array}{lll}0 & 0\end{array}\right]$ zones and second order lines fell into correspondence with those not already matched. Final unit cell parameters were $a=11.18(5), b=33.92(4), c$ $=3.88(9) ; \alpha=\beta=\gamma=90^{\circ}$. Systematic absences were most consistent with the space group Pnma. 
1. J. Laugier, B. Bochu, Laboratoire des Matériaux et du Génie Physique, Ecole Nationale Supérieure de Physique de Grenoble. http://www.inpg.fr/LMGP/.

2. K. Leinenweber. http://multianvil.asu.edu/Crystal_Cracker/CrystalCracker.html.

Figure 3. Stacked powder diffractograms for $\mathbf{1}$ and $\mathbf{2}$ showing the full patterns (from $2 \theta$ $=3-50^{\circ}$ ) and the region from $2 \theta=8-50^{\circ}$ (patterns scaled to normalized intensity) with crystallographic indices noted and the similar (101) $d$-spacings indicated for each compound. For both figures compound $\mathbf{1}$ is displayed as the lower plot and $\mathbf{2}$ as the upper plot.

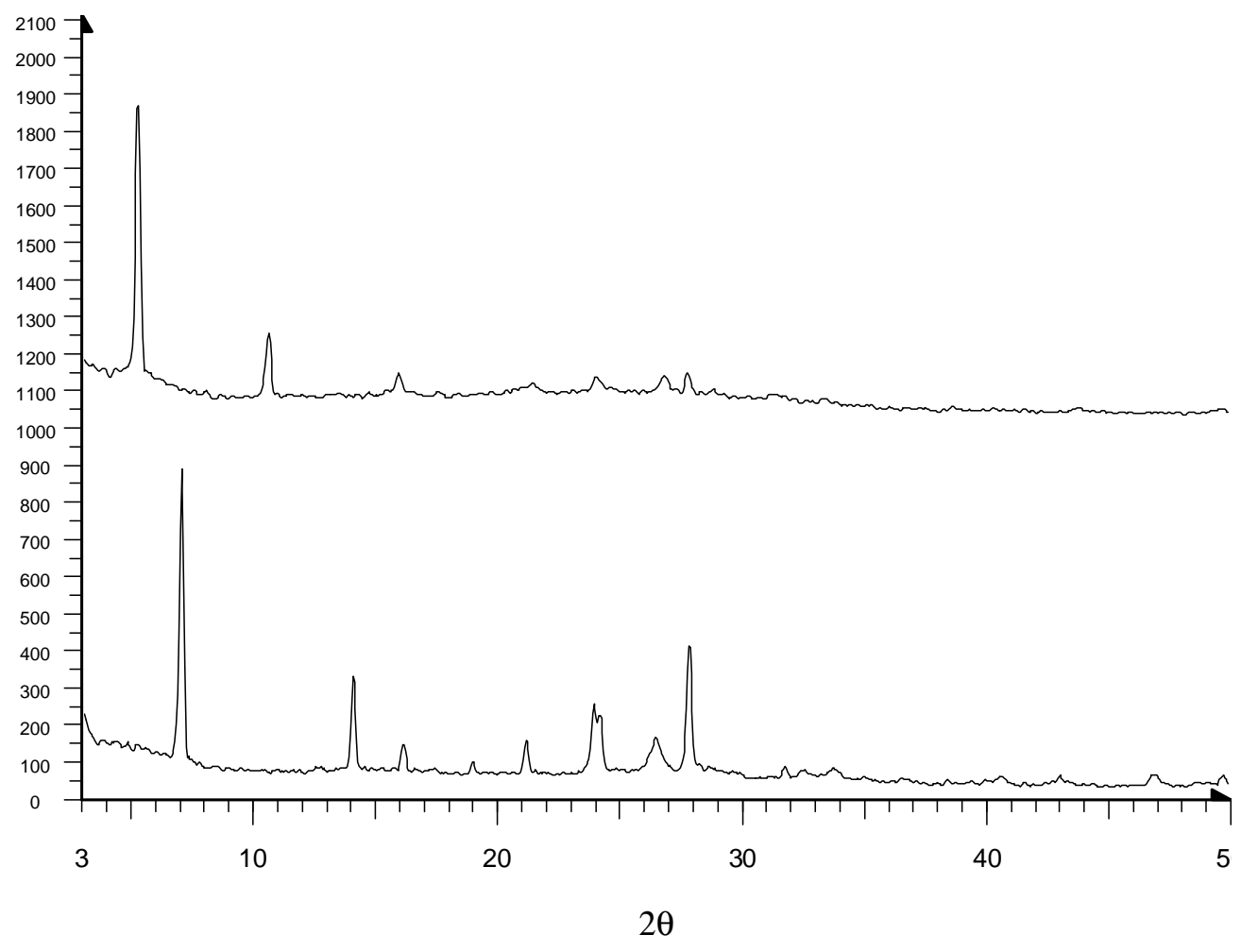




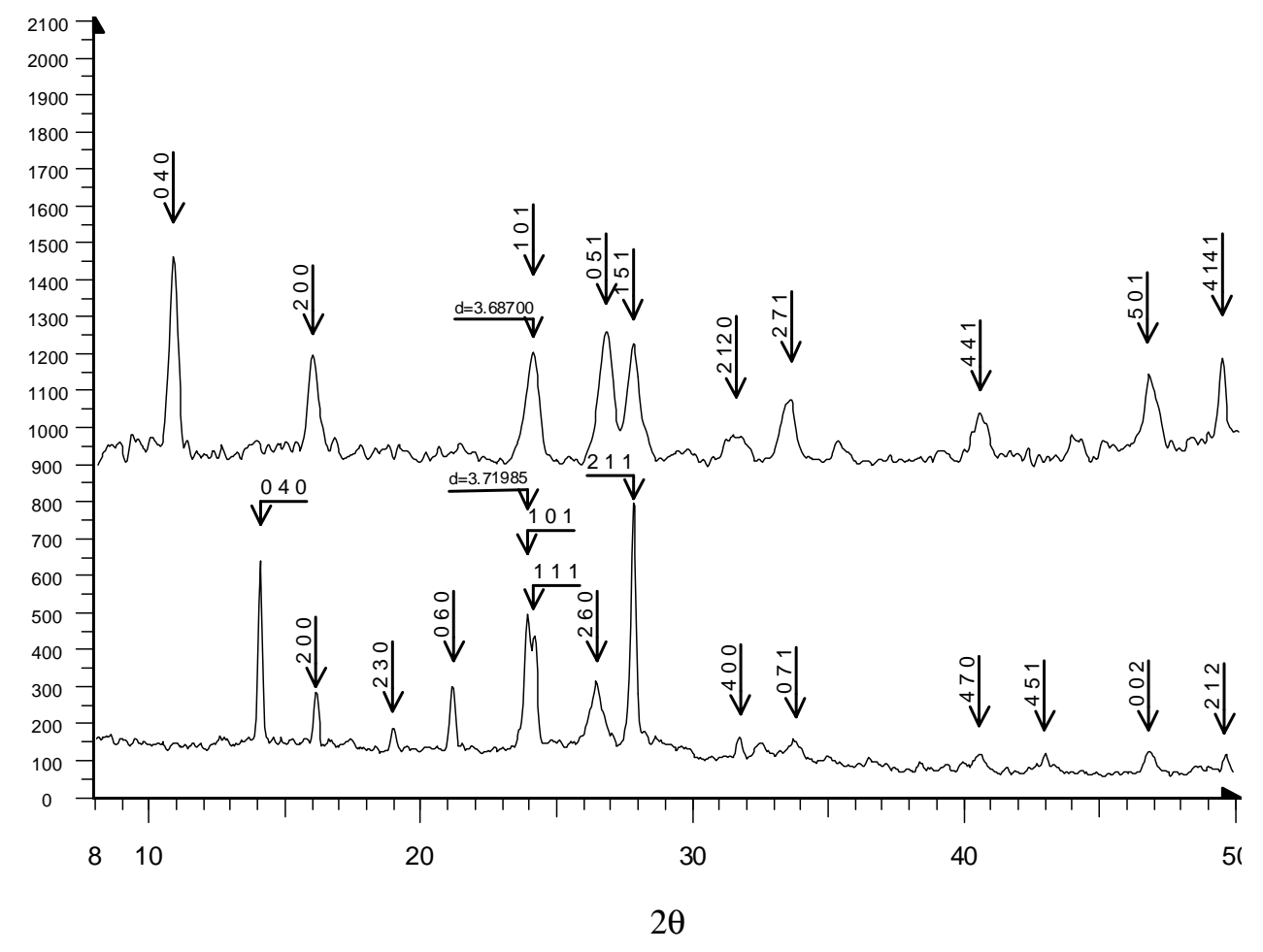

4. Normalized UV-vis and fluorescence spectra comparison of $7,12,1,2, \alpha$ terthiophene and $\alpha$-quaterthiophene (nm).
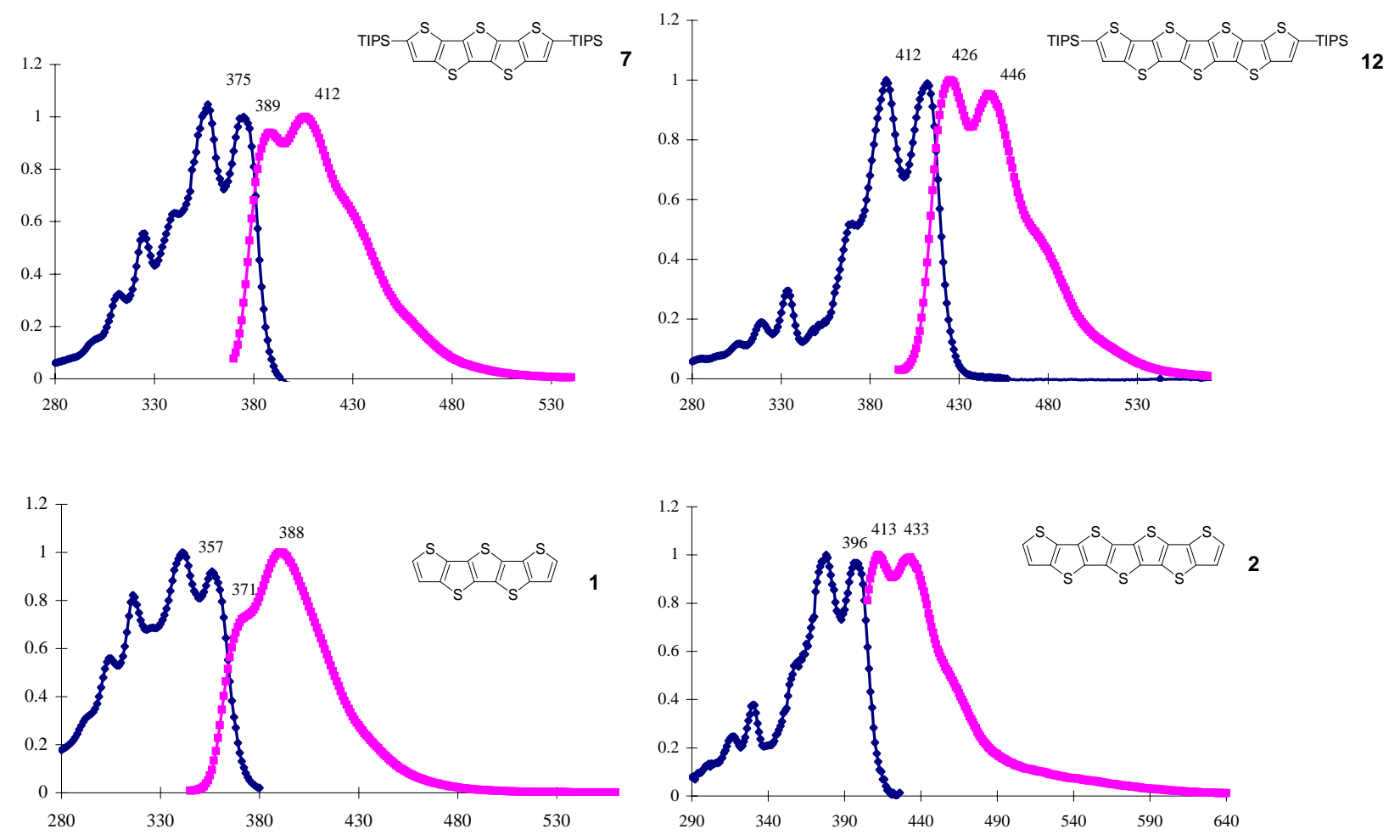

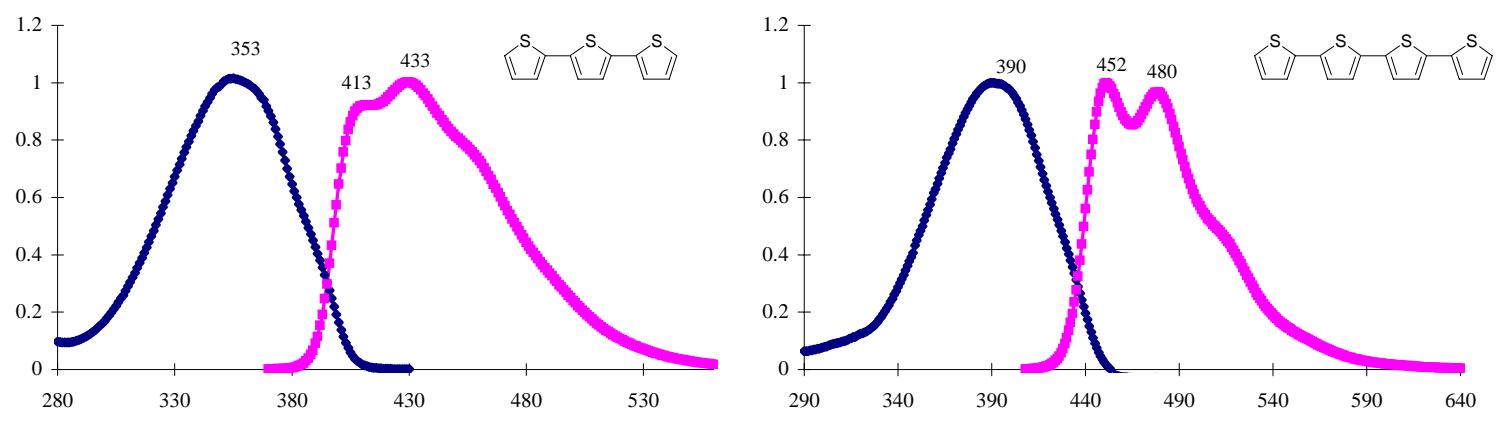

5. Cyclic voltammetry of 1.

Cyclic voltammetry experiments $(0.1 \mathrm{M}$ tetrabutylammonium hexafluorophosphate in $\mathrm{CH}_{3} \mathrm{CN}$ ) were performed using a Princeton Applied Research Potentiostat/Galvanostat Model 263A with platinum as the working electrode, a platinum wire counter electrode, and $\mathrm{Ag} / \mathrm{Ag}^{+}$reference electrode. Because of its poor solubility, measurements were made on a film of compound $\mathbf{1}$ prepared by drop casting on the working electrode from $\mathrm{CHCl}_{3}$ solution. The oxidation process of $\mathbf{1}$ was irreversible (Figure 5).

Figure 5. Cyclic voltammetry of compound $\mathbf{1}$.

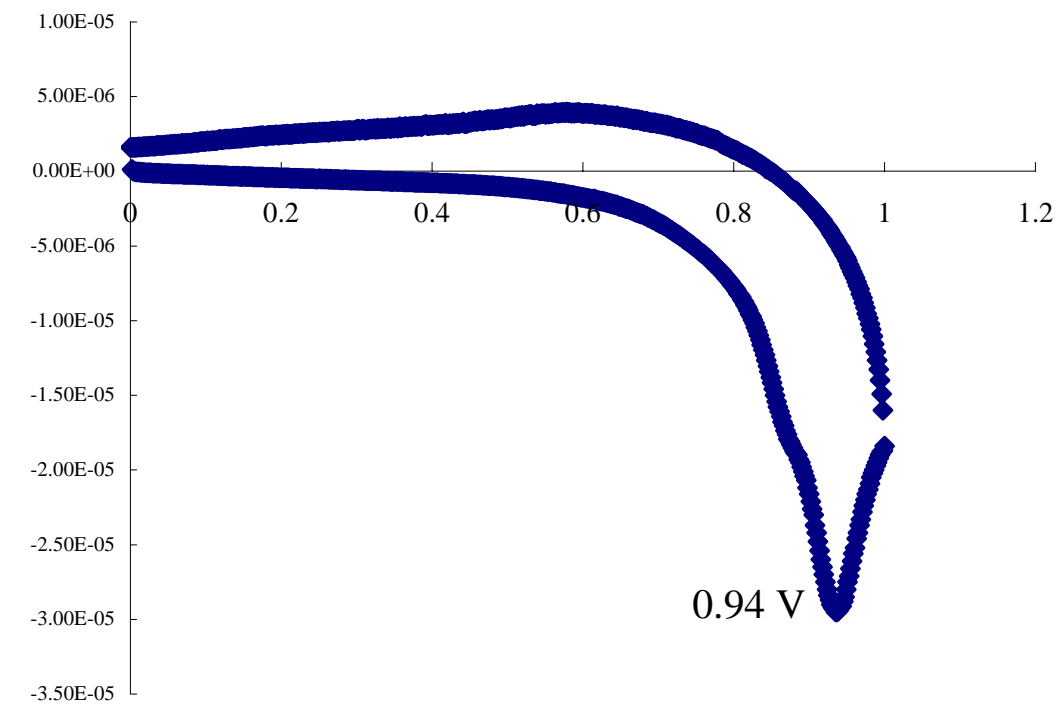

\section{REFRENCES:}

(1) Jung, S. H.; Kim, H. K.; Kim, S. H.; Kim, Y. H.; Jeoung, S. C.; Kim, D. Macromolecules 2000, 33, 9277-9288.

(2) Frey, J.; Bond, A. D.; Holmes, A. B. Chem. Commun. 2002, 2424-2425. 